\title{
Dimethylsulfoniopropionate in a salt marsh estuary: correlation to tidal cycle and phytoplankton assemblage composition
}

\author{
Nitin R. Kulkarni ${ }^{1}$, David L. White ${ }^{4}$, Alan J. Lewitus ${ }^{2,3}$, Raphael G. Tymowski ${ }^{2}$, \\ Duane C. Yoch ${ }^{1, *}$
}

${ }^{1}$ Department of Biological Sciences, and ${ }^{2}$ Belle W. Baruch Institute for Marine and Coastal Sciences, University of South Carolina, Columbia, South Carolina 29208, USA

${ }^{3}$ Marine Resources Research Institute, South Carolina Department of Natural Resources, Charleston, South Carolina 29412, USA

${ }^{4}$ National Oceanic and Atmospheric Administration - Hollings Marine Laboratory, Charleston, South Carolina 29412, USA

\begin{abstract}
Salt marsh estuaries emit high levels of dimethylsulfide (DMS), yet little is known about the contribution of tidal creeks, which are rich in phytoplankton that can potentially produce dimethylsulfoniopropionate (DMSP). Quantitative data is presented on the relationship between phytoplankton assemblage structure during tidal cycles in North Inlet, a high-salinity salt marsh estuary near Georgetown, South Carolina. While there was little or no correlation between chlorophyll a (chl a) and phytoplankton DMSP (DMSPp) in tidal-creek waters, the DMSPp:chl a ratio showed a strong correlation with tidal stage, being highest at high slack tide and lowest at low slack tide. Phytoplankton assemblage structure determined from HPLC pigment profiles and CHEMTAX analysis (a matrix factorization program to derive taxonomic composition from photopigment ratios) showed that DMSP-rich taxa were highly correlated with the high DMSP:chl a values which occurred at high tide. These were haptophytes, dinoflagellates, cyanobacteria and cryptophytes. Diatoms had a lower correlation coefficient but, because they represented almost $40 \%$ of the algal biomass during the tidal cycle, this group could be a significant contributor of DMSPp at high tide. Chlorophytes, prasinophytes, and some chrysophytes showed a strong negative correlation coefficient (r) with the DMSPp:chl a peak. We conclude that the increase in the DMSPp:chl a ratio at high tide is due to an increased contribution of DMSP-rich phytoplankton taxa that enter the creeks from coastal waters during flood tide, and low values resulted from low DMSP-containing resuspended benthic microalgae, advected from the adjacent salt marsh into the tidal creeks during ebb tide. The data indicate a strong tidal effect on DMSP concentration that is a function of change in phytoplankton assemblage structure.
\end{abstract}

KEY WORDS: Dimethylsulfoniopropionate - DMSP · Phytoplankton assemblages · Pigments · CHEMTAX

Resale or republication not permitted without written consent of the publisher

\section{INTRODUCTION}

The dynamics of dimethylsulfide (DMS) in the marine environment are known to be associated with the production of dimethylsulfoniopropionate (DMSPp) by phytoplankton (Ackman et al. 1966, Turner et al. 1988, Kettle et al. 1999); however, DMSP is weakly correlated with phytoplankton biomass (Andreae \& Barnard 1984,
Leck et al. 1990). DSMP is present in certain groups of phytoplankton where it functions as a compatible solute for osmoregulation in marine algae and phytoplankton (Dickson et al. 1980, Vairavamurthy et al. 1985, Dickson \& Kirst 1986). In addition, DMSP acts as an antioxidant against environmental stresses, a cryoprotectant, an important source of microbial $\mathrm{C}$ and $\mathrm{S}$, and as an antigrazing agent (Simó 2001, Zubkov et al. 2001, Sunda et al. 2002). 
DMSP is found in such taxonomic groups as prasinophytes, haptophytes (prymnesiophytes), chrysophytes and dinoflagellates (Vairavamurthy et al. 1985, Keller et al. 1989a) and is the principle intermediate in the production of DMS that arises from cleavage of the DMSP C-S bond by a lyase enzyme in marine organisms (de Souza \& Yoch 1995). While most research on DMSPp and DMS emissions have been conducted in oceanic environments, salt marshes and coastal wetlands produce much higher levels of both on a unit area basis (Steudler \& Peterson 1984). However, in these systems, the DMSP-producing properties of phytoplankton have received little attention. One study of bays on the northeastern US coast showed pronounced nonlinear relationship between salinity and DMSPaq (aqueous), DMSPp and DMSaq levels, when normalized to chlorophyll a (chl a) (Iverson et al. 1989). According to Iverson et al. (1989), this nonlinear relationship suggested that certain phytoplankton species, present in the more saline coastal waters, were important contributors of DMSPp and DMS. As supporting evidence, they reported that the phytoplankton of estuarine waters was dominated by diatoms (Bacillariophyceae) while more saline nearshore and oceanic waters were populated primarily by coccolithophores (Haptophyceae). The latter are known to be rich in DMSP compared to diatoms (Vairavamurthy et al. 1985, Keller et al. 1989a). Salinity also seemed to play a role in DMS emissions from the surface of coastal marshes in Louisiana, as evidenced by the magnitude of emissions, being: salt marshes > brackish marshes $>$ freshwater marshes (DeLaune et al. 2002). Phytoplankton species composition was not determined in DeLaune et al.'s (2002) study. For recent reviews of DMSP and DMS production and metabolism see Kiene et al. (1996) and Yoch (2002).

We have carried out monthly surveys since 2000 on the relationship between phytoplankton biomass (measured as chl a) and DMSPp in tidal creeks in a shallow, high-salinity estuary on the southeastern US coast. When it became apparent that these values changed dramatically during a tidal cycle, analysis of accessory pigments and a matrix factorization program (CHEMTAX) (Mackey et al. 1996) was used to determine phytoplankton taxonomic composition. This technique allowed us to monitor the dynamics of the phytoplankton community structure during a tidal cycle and compare these changes with DMSPp and chl a levels. This is the first report in estuarine ecology that a flood tide brings in high DMSP-producing pelagic groups of microalgae which greatly increases the ratio of DMSPp:chl a. When these species were carried out on the ebb tide and the lower DMSP-producing benthic microalgal taxa were resuspended and washed into the creeks, the DMSPp:chl a ratio decreased dramatically.

\section{MATERIALS AND METHODS}

Site description. Sampling and observations described in this study were in tidal creeks (Clambank and Crabhaul Creek) in the near-pristine North Inlet salt marsh-estuarine ecosystem (Fig. 1). North Inlet is a shallow, tidally dominated estuary characterized by extensive (2500 ha) Spartina alterniflora Loisel. salt marshes, about 850 ha of tidal creeks, and intertidal oyster reefs with tidal-creek water salinities similar to nearshore waters. It is located at $33^{\circ} 20^{\prime} \mathrm{N}, 79^{\circ} 10^{\prime} \mathrm{W}$ near the city of Georgetown on the northeastern coast of South Carolina, USA. The estuary is bordered by a 1000 ha pine forest (Pinus teada) which releases low intermittent freshwater flow into the marshes. Dissolved substances in North Inlet are vertically homogeneous (Kulkarni unpubl.) due to the shallow nature of the tidal creeks and the strong tidal exchange, which also prevent salinity stratification (Kjerfve 1986, Lewitus et al. 2002). At Clambank and Crabhaul Creeks the approximate tidal amplitude was measured as $1 \mathrm{~m}$ and the average depth at high tide as $1.5 \mathrm{~m}$. The

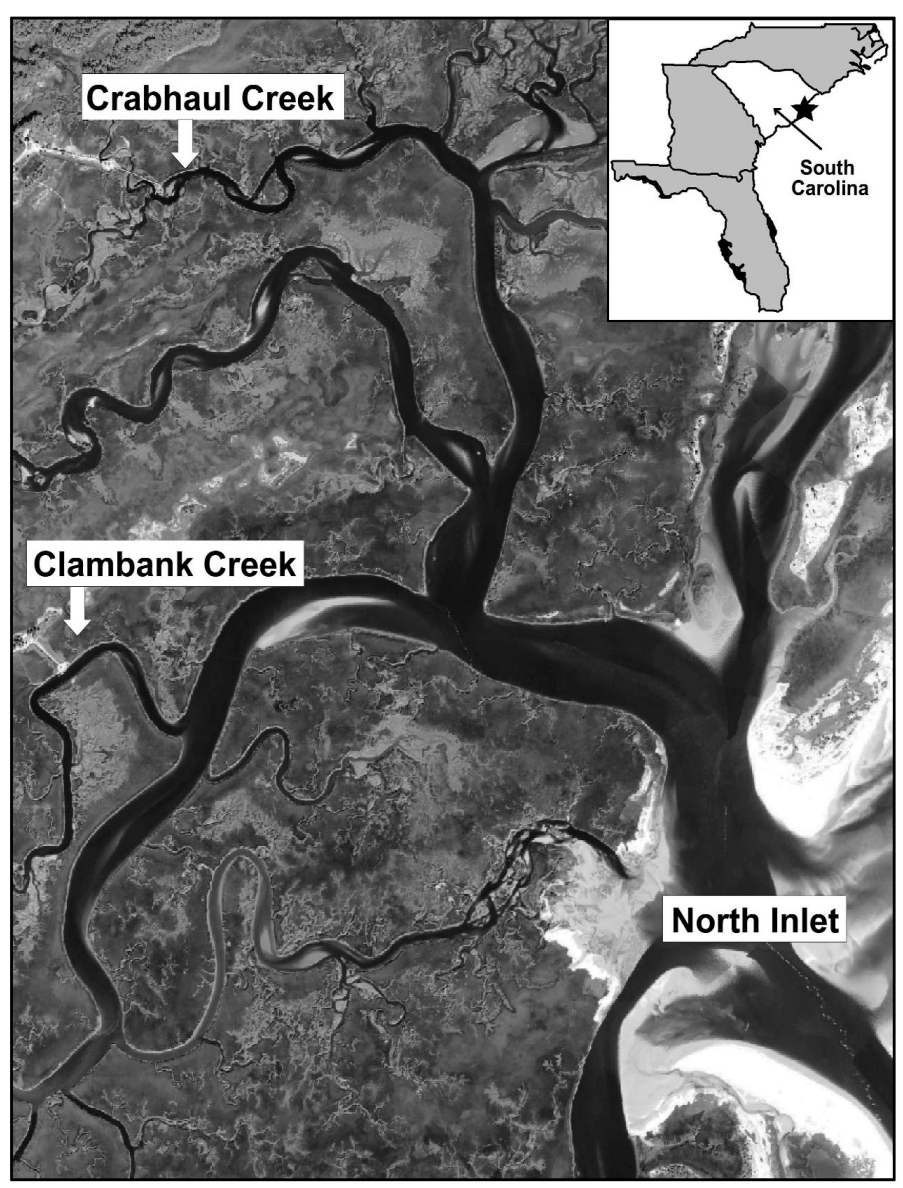

Fig. 1. Study sites in tidal creeks of North Inlet, South Carolina. Clambank and Crabhaul Creek are the tidal-creek sites 
coastal site where nearshore water samples were collected was a sandy beach located at $33^{\circ} 23^{\prime} 58.97^{\prime \prime} \mathrm{N}$, $79^{\circ} 8^{\prime}$ 8.45" W at Pawley's Island, South Carolina, which is north of North Inlet.

Sampling protocol. All sample collecting was done during the summer and fall of 2001 and 2002. Triplicate water samples from creeks were collected at selected stages of a tidal cycle from $20 \mathrm{~cm}$ below the surface and approximately $2 \mathrm{~m}$ from the bank using 11 acid-washed plastic bottles. The sampling site at Clambank Creek was midway (1.5 miles, $2.4 \mathrm{~km}$ ) from the mouth of the North Inlet and its terminus. At the coastal site, triplicate water samples were collected from $20 \mathrm{~cm}$ below the surface from water ca. $1.2 \mathrm{~m}$ deep (50 $\mathrm{m}$ from shore). Samples were stored in the dark at ambient water temperature and immediately taken to the field laboratory for filtration and analysis.

Benthic microalgae, which are known to be resuspended in the intertidal zone during late ebb tide and early flood tide (Roman \& Tenore 1978, Baillie \& Welsh 1980) were also analyzed for their DMSPp:chl a ratio. Sites chosen for sample collection were both on open mud flats and from Spartina alterniflora-covered areas. We took 4 samples in the intertidal zone at Clambank Creek, ca. $200 \mathrm{~m}$ apart, where the water was 10 to $15 \mathrm{~cm}$ deep ( $2 \mathrm{~h}$ after high tide). The water was gently agitated by hand to resuspend the benthic flora from the uppermost sediment surface. This layer is most likely to be disturbed by tidal shear. The DMSPp:chl a ratios were compared between the tidal-creek waters and the resuspended benthic algae from the intertidal zone.

Samples for vertical profiling of Clambank Creek were taken in triplicate at the surface and 0.75 and $1.5 \mathrm{~m}$ depth at high tide using acid-washed, stoppered polypropylene bottles that were opened at the desired depth. The constant DMSP:chl a ratios confirmed that this is a well mixed estuary.

DMS/DMSPp analysis. Phytoplankton DMSPp was measured as DMS $24 \mathrm{~h}$ after the addition of $10 \mathrm{~N}$ $\mathrm{NaOH}$ to material retained by Whatman GF/F filters ( $0.7 \mu \mathrm{m}$ nominal pore size). While this filtered material included detritus, zooplankton and fecal pellets, the DMSPp was assumed to be primarily from phytoplankton (Yoch 2002). DMS was analyzed by gas chromatography on a Shimadzu Model GC-8A equipped with a flame ionization detector (FID) described by (de Souza \& Yoch 1995). Standard curves were prepared for each set of analyses with commercial DMSP (Research Plus).

Filter-based size fractionation. Fractionation of microalgae at Clambank Creek was performed on 15 August and 5 December 2002 to determine the size distribution of the DMSP-containing phytoplankton. Water samples (ca. $100 \mathrm{ml}$ ) were filtered by gravity filtration pressure through nylon filters $(125,48$ and $20 \mu \mathrm{m})$ or by applying a very low ( $<100 \mathrm{~mm} \mathrm{Hg}$ ) negative hydrostatic pressure to $47 \mathrm{~mm}$ Whatman GF/F or GF/D glass-fiber filters $(0.7$ and $2.7 \mu \mathrm{m}$ nominal pore size, respectively).

Phytoplankton photopigment analysis. Chl a estimation: $\mathrm{Chl}$ a served as an estimator of algal biomass and was assayed in parallel with DMSP. Triplicate samples were collected and filtered with Whatman GF/F (pore size $0.7 \mu \mathrm{m}$ ) glass-fiber filters. The filters were stored on dry ice or in a $-70^{\circ} \mathrm{C}$ freezer, then immersed in $90 \%$ acetone, ground with a glass rod, placed in the dark overnight at $4^{\circ} \mathrm{C}$, vortexed, and centrifuged. Fluorescence was measured using a TD-700 Laboratory Fluorometer (Turner Designs, Sunnyvale, California) according to standard US Environmental Protection Agency methods (Arar \& Collins 1997), as described in the manufacturer's handbook, and compared to that of a purified standard of Anacystis nidulans chl a (Sigma-Aldrich).

Other photopigments: Phytoplankton assemblage composition in the samples collected on 29 October 2002 at the Clambank Creek at $2 \mathrm{~h}$ intervals throughout the tidal cycle was assessed from HPLC pigment profiles and a matrix factorization program (CHEMTAX) used to derive taxonomic composition from photopigment ratios. For HPLC, frozen filters were stored at $-80^{\circ} \mathrm{C}$. Frozen filters were immersed in $2 \mathrm{ml}$ of $100 \%$ HPLC-grade acetone and were broken up using a vortex mixer. The resulting slurry was stored overnight at $-20^{\circ} \mathrm{C}$, vortexed, and filtered through a $13 \mathrm{~mm}$, $0.2 \mathrm{~mm}$ PTFE syringe filter. The extracts were stored at $-20^{\circ} \mathrm{C}$ pending analysis. Samples were analyzed using a Beckman system Gold HPLC with a Beckman 125 dual pump unit, a manual injection valve with a $200 \mu \mathrm{l}$ sample loop, an Agilent Eclipse XDB-C8 $150 \times 4.6 \mathrm{~mm}$, $3.5 \mu \mathrm{m}$ particle-size column, an Eldex $\mathrm{CH}-150$ column heater, and a Beckman 168 diode array detector (DAD). The analysis was performed using the method of Van Heukelem \& Thomas (2001), with flow rate and gradient times modified for the instrument. This method uses a 2-solvent system: Solvent A (28 mM tetrabutylammonium hydroxide adjusted to $\mathrm{pH}$ of 6.50 with glacial acetic acid, mixed with HPLC-grade methanol in a 30:70 ratio by volume) and Solvent B (HPLC-grade methanol). The column was maintained at $60^{\circ} \mathrm{C}$. The chromatograms were based on DAD absorbance measurements at $450 \mathrm{~nm}$ with a $20 \mathrm{~nm}$ bandwidth. Pigments were identified by comparing their retention times and absorption spectra to those of standards.

CHEMTAX, a matrix factorization program run using MATLAB $^{\circledR}$ (MathWorks), uses a steepest-descent algorithm to fit a matrix containing the expected pigment ratios of several taxonomic groups to one consisting of the actual pigment content of unknown samples (Mackey et al. 1996). CHEMTAX has been success- 
fully applied to oceanic communities using pigment data obtained from the literature (Mackey et al. 1996, Wright et al. 1996, Higgins \& Mackey 2000, Wright \& Van den Enden 2000). Our method applies CHEMTAX to North Inlet estuarine phytoplankton assemblages using a calibration matrix based on pigment ratios obtained primarily from estuarine phytoplankton isolates (Lewitus et al. 2005).

Phytoplankton photopigment characteristics. Our CHEMTAX method yields the following taxonomic groups based on the pigments indicated.

- Prasinophyceae A: prasinophytes without prasinoxanthin. Pigments include lutein, zeaxanthin, violaxanthin, neoxanthin, and chl $b$.

- Prasinophyceae B: prasinophytes with prasinoxanthin. Because we have no representative estuarine isolates, the oceanic isolate-based pigment ratios of Mackey et al.'s (1996) 'Prasinophyceae Type 2' were used for calibration of this group.

- Haptophyceae A: haptophytes without 19' hexanoyloxyfucoxanthin (19'hex) or 19' butanoyloxyfucoxanthin (19'but), but possessing $\mathrm{chl} C_{1}$, chl $C_{2}$, fucoxanthin, diadinoxanthin, and diatoxanthin. This group also includes chrysophytes (Chryso-A) and dinoflagellates (Dino-C) with similar pigments.

- Haptophyceae B: haptophytes with 19'hex and 19'but, chl $c_{3}$, fucoxanthin, diadinoxanthin, and diatoxanthin. Since no estuarine representative for this group was found, we used the Mackey et al. (1996) pigment ratios for 'Haptophyceae Type 4'.

- Dinophyceae B: dinoflagellates with peridinin, chl $<C_{2}$, diadinoxanthin, and diatoxanthin. This group excludes dinoflagellates with pigments indicative of ancestral endosymbionts (e.g. fucoxanthin, 19'hex, 19'but).

- Chrysophyceae B: this group is called Chryso-B because Chryso-A is used to designate the group of chrysophytes included with Haptophyceae A. Chryso-B are distinguished from Chryso-A by having 19'but. The ratios used were those of Mackey et al. (1996) for 'Chrysophyceae Type-2'. Pigments include $\mathrm{chl} c_{2}$, chl $c_{3}, 19^{\prime}$ but, fucoxanthin, diadinoxanthin, and diatoxanthin.

- Cyanophyceae: calibrated with both filamentous and coccoid estuarine isolates. Zeaxanthin was the only diagnostic carotenoid included.

- Raphidophyceae A: pigments include $\operatorname{chl} C_{1}, \operatorname{chl} C_{2}$, fucoxanthin, violaxanthin, diadinoxanthin, and zeaxanthin. The pigment ratios were based on Heterosigma akashiwo, and therefore this analysis is not applicable to raphidophytes with different pigment signatures.

- Bacillariophyceae: pigments include fucoxanthin, diatoxanthin, diadinoxanthin, $\operatorname{chl} c_{1}$ and $\operatorname{chl} c_{2}$. This pigment group also includes dinoflagellates with similar pigment composition (Dino-A). chl $C_{3}$ was not analyzed since it is a rare pigment in diatoms.

- Chlorophyceae: pigments include lutein, violaxanthin, zeaxanthin, neoxanthin, and chl $b$.

- Cryptophyceae: pigments include alloxanthin and chl $C_{2}$.

- Euglenophyceae: pigments include zeaxanthin, neoxanthin, lutein, diatoxanthin, diadinoxanthin, and $\mathrm{chl} b$.

Microscopic enumeration of fixed phytoplankton. Microscopic enumeration of fixed samples collected on 29 October 2002 from Clambank Creek was conducted using the Utermöhl (1958) method. After collection, each sample was placed on ice in a closed cooler for storage and transportation back to the laboratory, where $100 \mathrm{ml}$ subsamples were placed in $125 \mathrm{ml}$ polyethylene bottles with $3 \mathrm{ml}$ of acid Lugol's solution for preservation. Preservation generally occurred within 2 to $4 \mathrm{~h}$ of the initial collection. Samples were stored in the dark at a temperature of approximately $4^{\circ} \mathrm{C}$.

Microscopic counts on the fixed samples were made with an inverted microscope at $200 \times$ magnification using an Utermöhl settling chamber. The cells in chains or colonies were counted individually. The counting process continued until approximately 200 cells were counted or at least 15 fields of view were completed.

The Utermöhl technique with acid Lugol-stained samples was adequate for categorizing most of the phytoplankton community; however, the magnification range (maximum $400 \times$ where resolution permitted) resulted in the underestimation of smaller size classes of phytoplankton $(<5 \mu \mathrm{m})$. Also, identification of some species was confounded by loss of flagella or other cellular distortions associated with inadequate preservation by Lugol's solution.

Other measurements. Salinity was measured using a handheld Reichert-Jung refractometer. Light measurements were made using a LI-COR LI-188-B photometer.

Statistics. Relationships between the DMSPp:chl a ratio and phytoplankton class (identified by CHEMTAX) at the selected tidal stages, and between DMSPp and total chl a were examined using the Pearson product-moment correlation test (PROC CORR: SAS Institute 1999). This is a parametric measure of association, ranging from +1 to -1 for 2 continuous random variables. Probabilities $(\alpha=0.05)$ were calculated for each comparison and are also presented. A paired $t$-test (1-tail) was used to determine if the experimental DMSPp:chl a means between high tide and low tide were significantly different. Specifically, the SAS 'Analyst' functions were used to test if the high-tide DMSP:chl a was significantly greater than the low-tide DMSPp:chl a $(\alpha=0.05)$. 


\section{RESULTS}

\section{DMSPp and chl a distribution}

Concentrations of DMSPp in Clambank and Crabhaul Creek ranged from 13 to $141 \mathrm{nM}$. DMSPp and total phytoplankton biomass (chl a) were only weakly correlated ( $\mathrm{r}=0.34, \mathrm{p}=0.0166$, Fig. 2). Most creek samples were taken at high tide near the surface (10 to $20 \mathrm{~cm}$ ). Vertical profiles showed that chl $a$ and DMSPp concentrations from these shallow $(<2 \mathrm{~m})$, well mixed creeks were homogenous from surface to bottom (data not shown), allowing us to extrapolate our observations to the entire water column.

When variations in DMSPp and chl a were analyzed during a tidal cycle in which sunrise (daylight) coincided with slack low tide, chl a maxima occurred during the flood tide at about noon with a second smaller peak evident during the ebb tide (Fig. 3). Interestingly, DMSPp levels did not follow this pattern, but followed the tidal pattern being high at high tide and low at low tide. Since both tidal cycles analyzed occurred completely during daylight hours, any variability associated with diurnal effects was precluded.

\section{Size fractionation}

When DMSPp in the tidal-creek water was analyzed (15 August 2002) as a function of particle size, most (60\%) was in the 2.7 to $20 \mu \mathrm{m}$ nanoplankton range

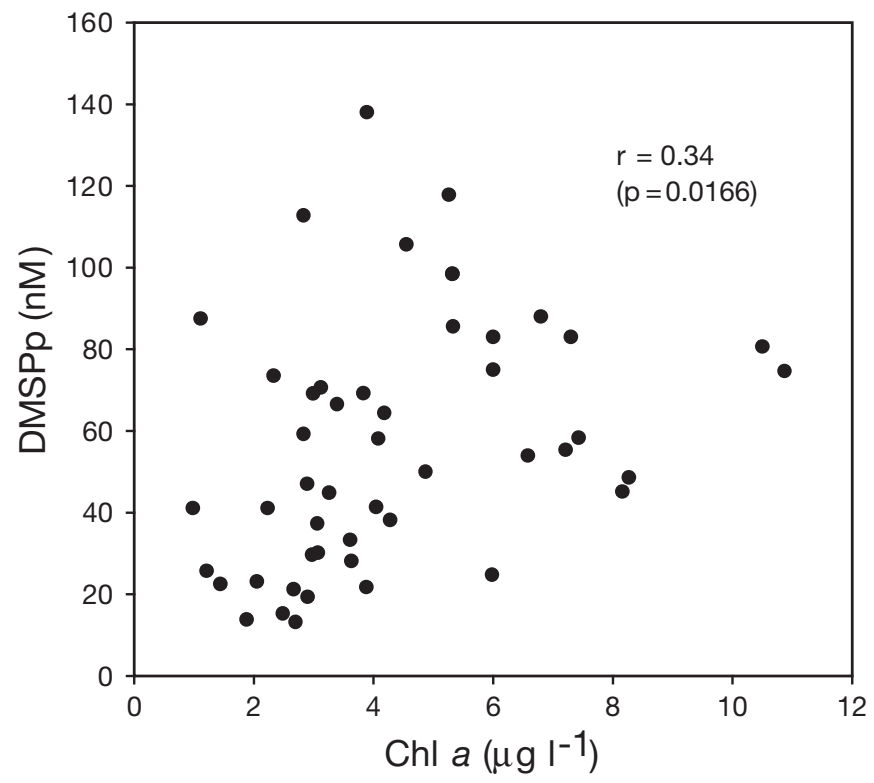

Fig. 2. Scatter-plot of all paired measurements of chlorophyll a (chl a) and DMSPp ( $\mathrm{n}=49)$. Samples were collected from Clambank and Crabhaul tidal creeks between June 2001 and February 2003

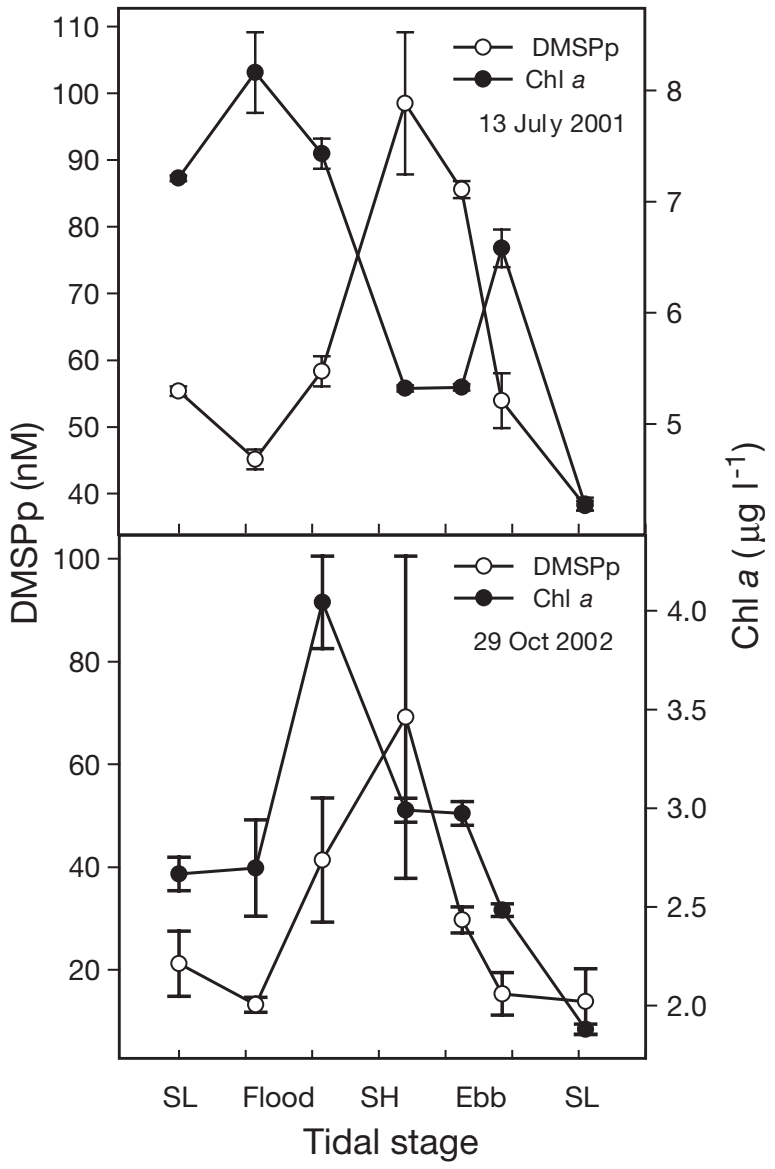

Fig. 3. Chlorophyll $a$ and DMSPp levels in a tidal creek at different stages of the tidal cycle. Data represent 2 tidal cycles (13 July 2001 and 29 October 2002). Water samples at each tidal stage $(n=3)$ were collected between ca. 06:00 and 19:00 h (all in daylight). Water samples were taken at depth of ca. $20 \mathrm{~cm}$. SL: slack low tide; SH: slack high tide. Higher July 2002 chl a values reflect a summer peak. Means \pm SD are shown

(Fig. 4). This size class, however, also contained most of the phytoplankton biomass ( $\mathrm{chl} \mathrm{a}$ ) and was therefore not significantly enriched in DMSPp, as is evident from the similar DMSP:chl a ratios in the different size fractions (see inset, Fig. 4).

\section{DMSPp:chl a ratios}

DMSPp:chl $a$ is an index of the relative concentration of DMSP in the water column normalized to phytoplankton biomass. Although a low correlation between DMSPp and chl a could be detected in the total estuarine data set (Fig. 2), their ratio was always highest in tidal creeks near slack high tide (SH) and lowest near slack low tide (SL) (Fig. 5). Fig. 5 is representative of 7 tidal cycles analyzed similarly at Crabhaul and 


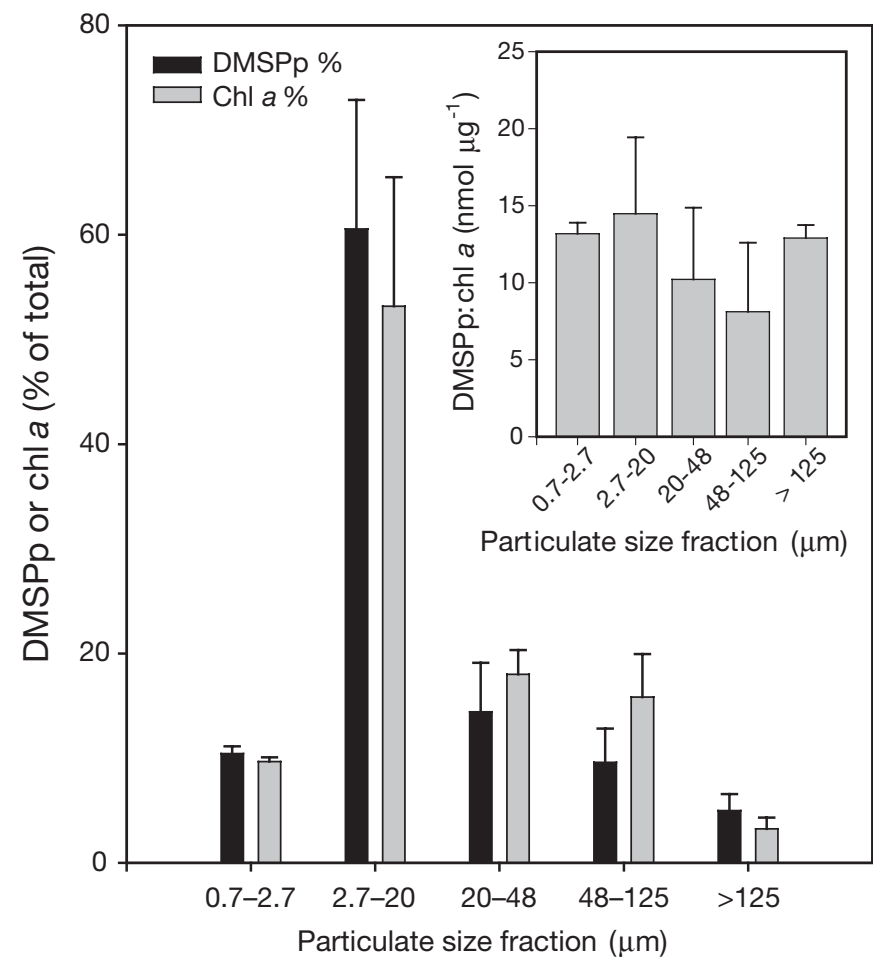

Fig. 4. Estimation of size fraction of chl a and DMSPp in Clambank Creek water (15 August 2002) at slack high tide expressed as percent of total. Inset: DMSPp:chl a ratios across different size classes of particulate matter. Whiskers on bars: $+\mathrm{SD}(\mathrm{n}=3)$

Clambank Creeks (data not shown). The difference in this ratio between high tide and low tide was always significant $(p=0.005)$. This phenomenon was peculiar to tidal creeks and not observed in nearby coastal waters (Pawley's Island, South Carolina) where the DMSPp:chl a ratio was clearly unaffected by the tidal stage. Measuring 3 points in the tidal cycle was sufficient to demonstrate this phenomenon (Fig. 5). When DMSPp:chl a was measured during a tidal cycle at night, the amplitude of the peak was sometimes not as great as during daylight cycles, but a distinct peak was always observed at high tide.

Factors were analyzed that might affect the DMSP:chl a values during the tidal cycle; these included light intensity (irradiance) and time of day (circadian rhythm). In an attempt to separate these potential contributing factors, tidal stage was kept constant by measuring DMSPp:chl a ratios during consecutive high tides occurring over a 12 d period (Fig. 6). Thus, tidal stage remained constant but, because high tide occurred at different times of the day, irradiance varied greatly. While irradiance had no apparent effect on the DMSPp:chl a ratio (Fig. 6A), this ratio spiked in the late afternoon (Fig. 6B). This seems to have been a result of a sharp drop in chl a between 15:00 and

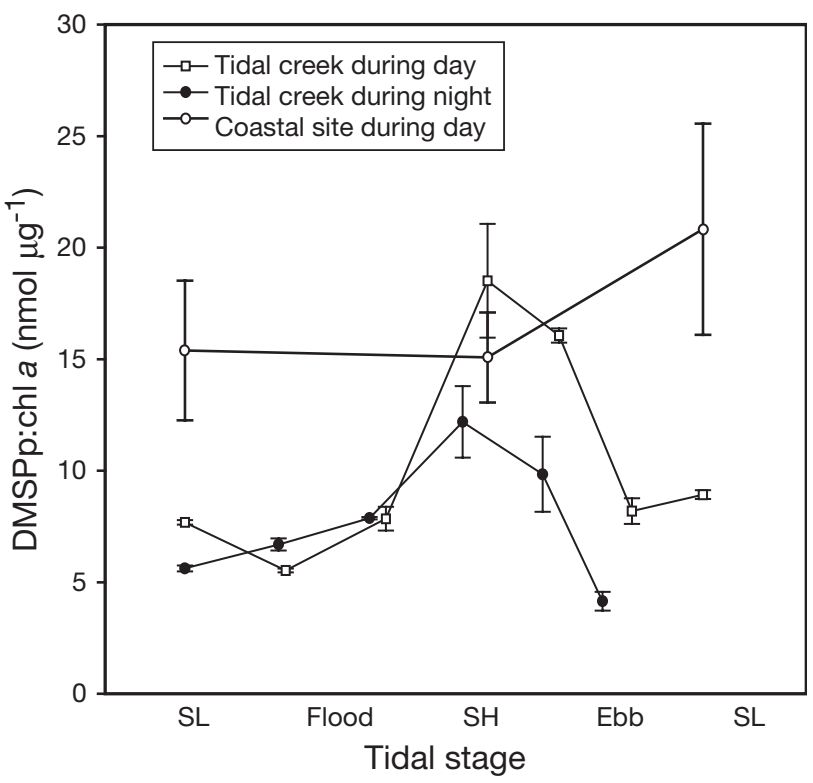

Fig. 5. Comparison of DMSPp:chl a ratios in Clambank Creek tidal cycles in daylight (13 July 2001) and at night (27 July 2001). Also shown are values obtained in daylight from the coastal site (Pawley's Island). Data are means \pm SD of triplicates taken during a single tidal cycle. SL: slack low tide; SH: slack high tide

17:00 h (data not shown). Therefore, some factor other than irradiance or time of day had to account for the high correlation of DMSPp:chl a with high tide in the tidal creeks.

\section{Phytoplankton assemblage composition}

Changes in phytoplankton assemblage composition during the tidal cycle were examined as a possible explanation for the high DMSPp:chl a levels at high tide. Composition during a daylight tidal cycle (29 October 2002) was determined by analysis of phytopigments or microscopic abundance estimates in samples taken at approximate $2 \mathrm{~h}$ intervals. Based on CHEMTAX analyses, phytoplankton composition in this experiment was seen to be dominated by diatoms and prasinophytes (40 and $32 \%$ of total assemblage composition, respectively) (Fig. 7). Microscopic counts verified the dominance of diatoms during this tidal cycle (Kulkarni unpubl. data). All other classes were represented at between $8 \%$ and zero (the Euglenophyceae).

Several phytoplankton groups correlated highly with the DMSPp:chl a ratio during the tidal cycle based on CHEMTAX quantitation (Fig. 8, Table 1); i.e. particular taxonomic groups showed positive correlations with the level of DMSP present in the assemblage 

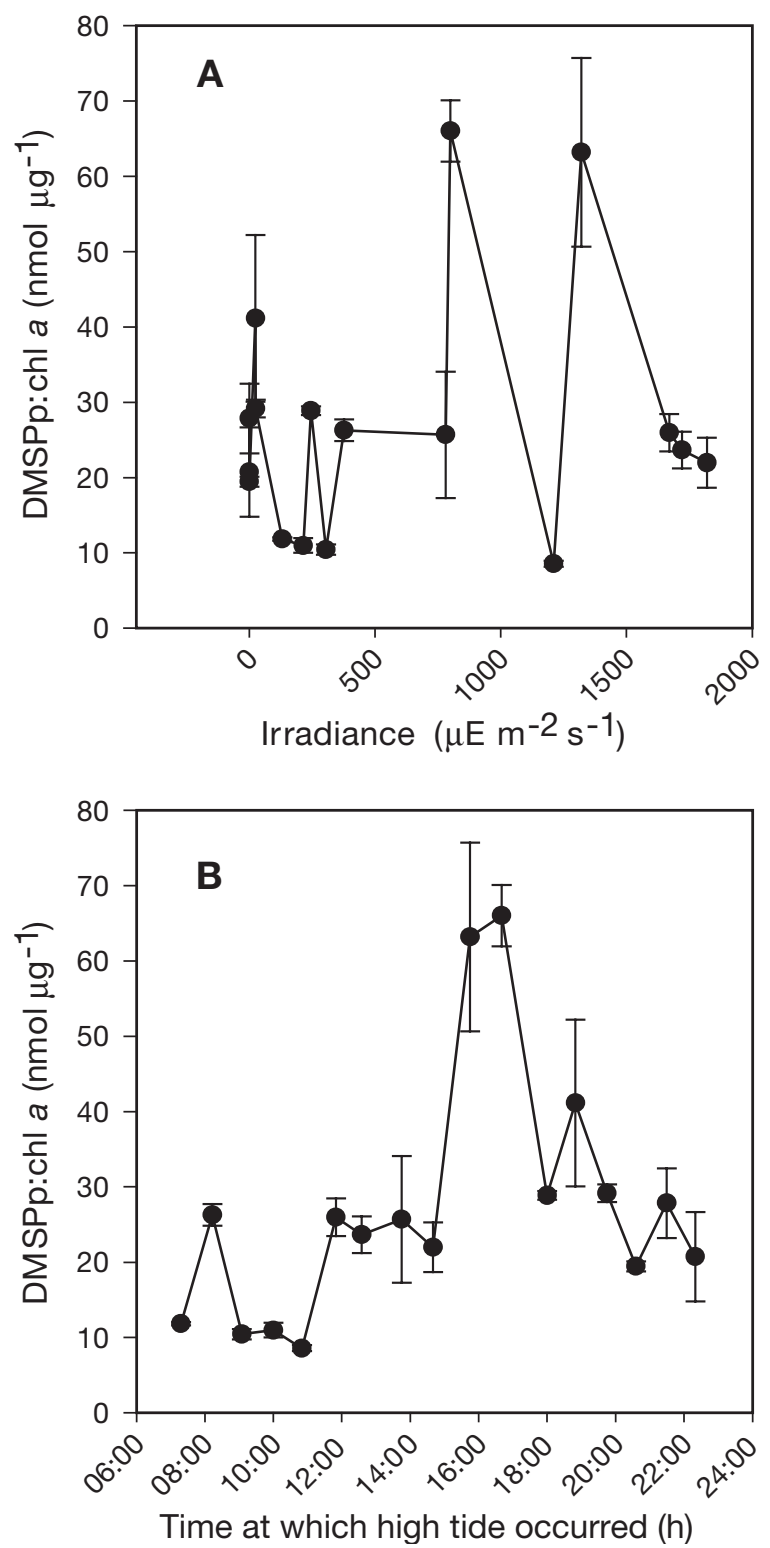

Fig. 6. DMSPp:chl a ratio trends at slack high tide plotted against (A) irradiance and (B) time of day at which high tide occurred $(\mathrm{n}=3)$. Values for Clambank Creek water were measured at consecutive high tides occurring at different times over a $12 \mathrm{~d}$ period (15 to 27 August 2001)

during the tidal cycle. Phytoplankton groups showing a positive correlation with the DMSPp:chl a ratio included Haptophyceae B, Dinophyceae B, Cyanophyceae, and Cryptophyceae. Diatoms had a lower correlation coefficient based on CHEMTAX ( $\mathrm{r}=0.24$, $\mathrm{p}=0.56)$, and microscopic abundance $(\mathrm{r}=0.18, \mathrm{p}=$ $0.70)$, neither of which was statistically significant. However, because diatoms represented $>40 \%$ of the total biomass (relative to $\mathrm{chl}$ a) during the tidal cycle (Fig. 7), this group is apparently a significant contri-

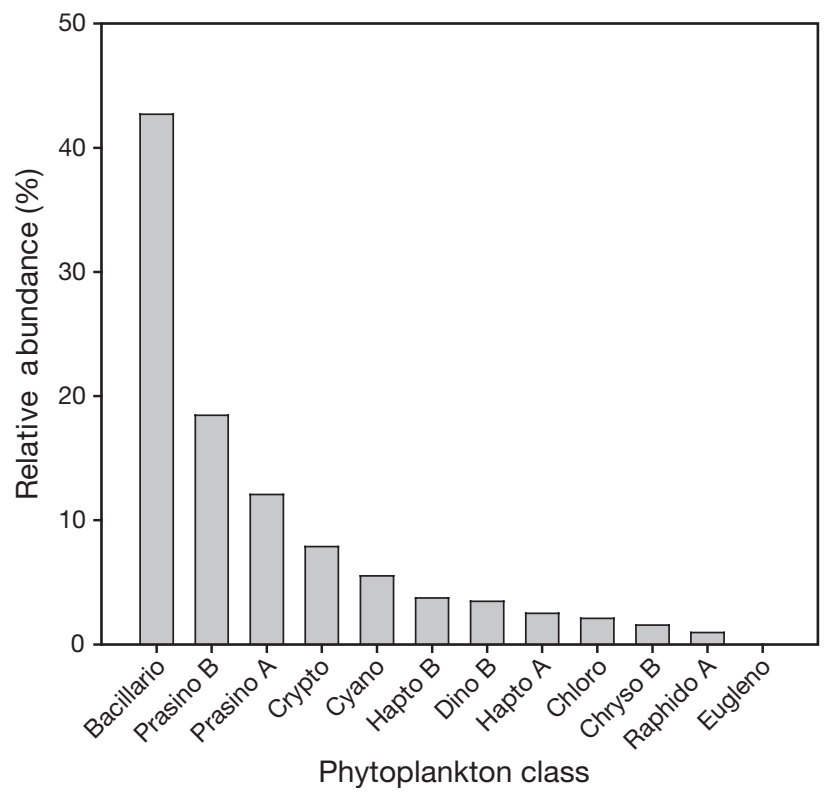

Fig. 7. Relative composition of phytoplankton classes in Clambank Creek water column integrated over entire (daylight) tidal cycle from 07:30 to 20:00 h on 29 October 2002, based on CHEMTAX analysis

butor of DMSPp in the water column at high tide. The microscopic counts of centric diatoms, relative to pennate (centric:pennate ratio), showed a trend similar to the DMSPp:chl a ratio (Fig. 9). This suggests that the pennate diatoms are being resuspended from the intertidal zone during flood and ebb tide. Based on these pigment data, some groups showed a significant negative correlation with the DMSPp:chl a ratio (Fig. 8B, Table 1). These data suggest that the increase

Table 1. Correlation of DMSPp:chlorophyll a (chl a) ratios with phytoplankton groups using CHEMTAX-based biomass. Tidal-creek water collected during daytime tidal cycle on 29 October 2002. nd: not determined. Correlation coefficient (r) is given with $\mathrm{p}$-values in parentheses

\begin{tabular}{|lc|}
\hline $\begin{array}{l}\text { Phytoplankton } \\
\text { groups }\end{array}$ & $\begin{array}{l}\text { Correlation of DMSPp:chl a ratio } \\
\text { to CHEMTAX-derived biomass }\end{array}$ \\
\hline $\begin{array}{ll}\text { Haptophyceae B } \\
\text { Dinophyceae B }\end{array}$ & $0.91(0.0042)$ \\
Cyanophyceae & $0.88(0.0091)$ \\
Cryptophyceae & $0.87(0.0118)$ \\
Raphidophyceae A & $0.61(0.1461)$ \\
Bacillariophyceae & $0.31(\mathrm{nd})$ \\
Haptophyceae A & $0.24(0.5997)$ \\
Euglenophyceae & $-0.02(\mathrm{nd})$ \\
Prasinophyceae B & $-0.17(\mathrm{nd})$ \\
Prasinophyceae A & $-0.54(0.2085)$ \\
Chlorophyceae & $-0.63(0.1258)$ \\
Chrysophyceae B & $-0.72(0.06)$ \\
\end{tabular}



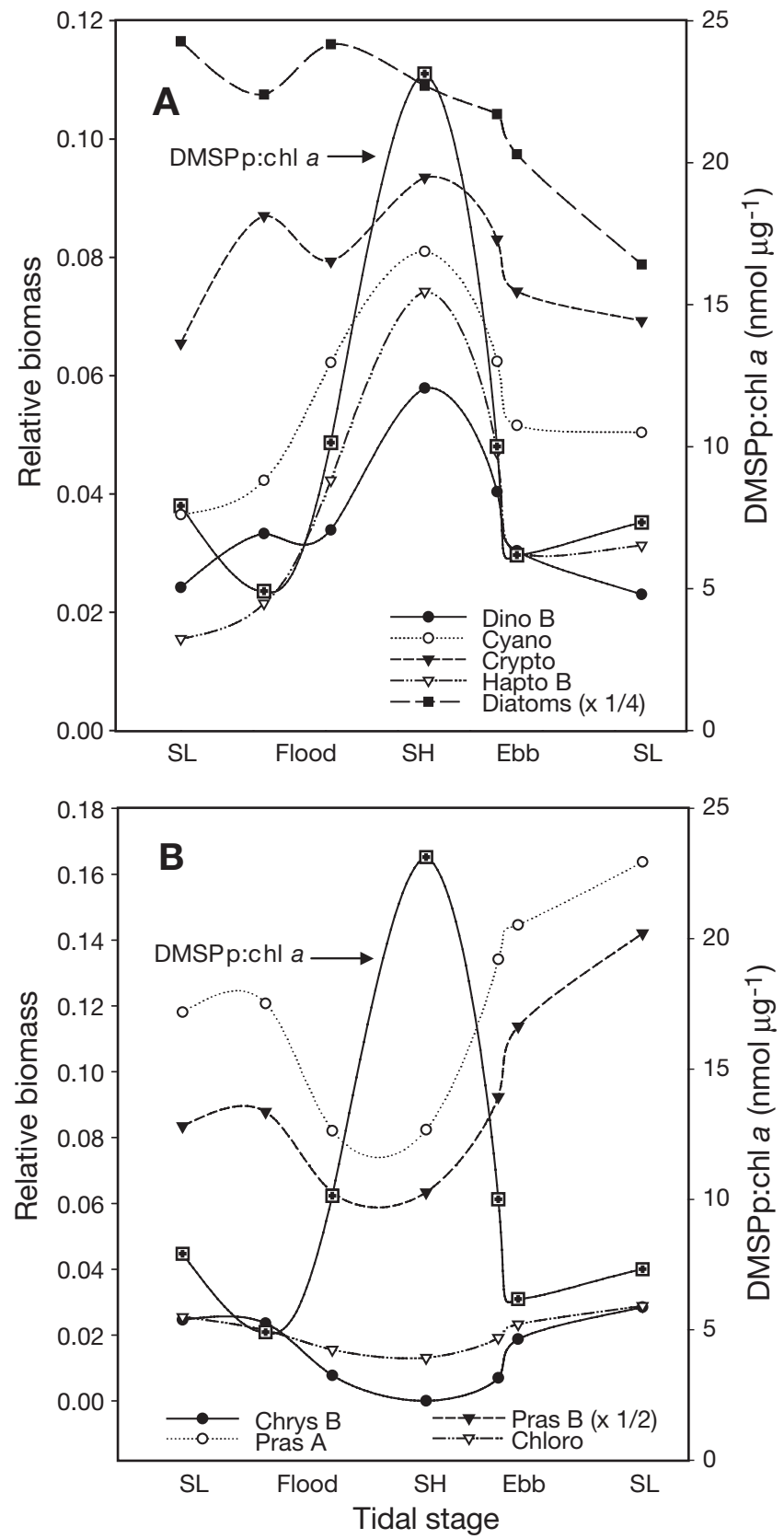

Fig. 8. Variation in phytoplankton class biomass (relative to chl a) and DMSPp:chl a ratio during a tidal cycle at Clambank Creek during the day from 07:30 to 20:00 h on 29 October 2002. Phytoplankton classes are shown that were (A) positively correlated or (B) negatively correlated with DMSPp:chl a ratio. Relative biomass of Diatoms and Pras B were multiplied by $1 / 4$ and $1 / 2$, respectively. Dino: Dinophyceae; Cyano: Cyanophyceae; Hapto: Haptophyceae; Crypto: Cryptophyceae; Chrys: Chrysophyceae; Pras: Prasinophyceae. SL: slack low tide; SH: slack high tide

in DMSPp at high tide is due in part to an increased contribution of phytoplankton species containing relatively high cellular DMSP that enter the creeks from coastal waters with the flood tide.
To determine if there was an agreement between CHEMTAX-derived biomass and microscopic cell counts for each phytoplankton group, correlation analyses were performed. Substantial differences resulted from the 2 methodologies. Whereas correlations of some groups like diatoms $(\mathrm{r}=0.49)$ and prasinophytes $(\mathrm{r}=0.76)$ were relatively high, these methods were poorly correlated when used to quantitate dinoflagelletes $(\mathrm{r}=0.2)$, haptophytes $(\mathrm{r}=0.25)$, raphidophytes $(\mathrm{r}=$ $0.35)$, chrysophytes $(r=-0.33)$, chlorophytes $(r=-0.33)$ and cryptophytes $(\mathrm{r}=-0.33)$. The problem appeared to be the difficulty in differentiating between chrysophytes, chlorophytes and cryptophytes in samples that were fixed in acid Lugol's solution. Compounding this problem was the fact that approximately $10 \%$ of the smaller cells, which also included the cyanobacteria, could not be identified under our protocol. It was not, however, unexpected that cell abundance did not correlate with pigment biomass, since the amount of pigment per cell can vary taxonomically and physiologically.

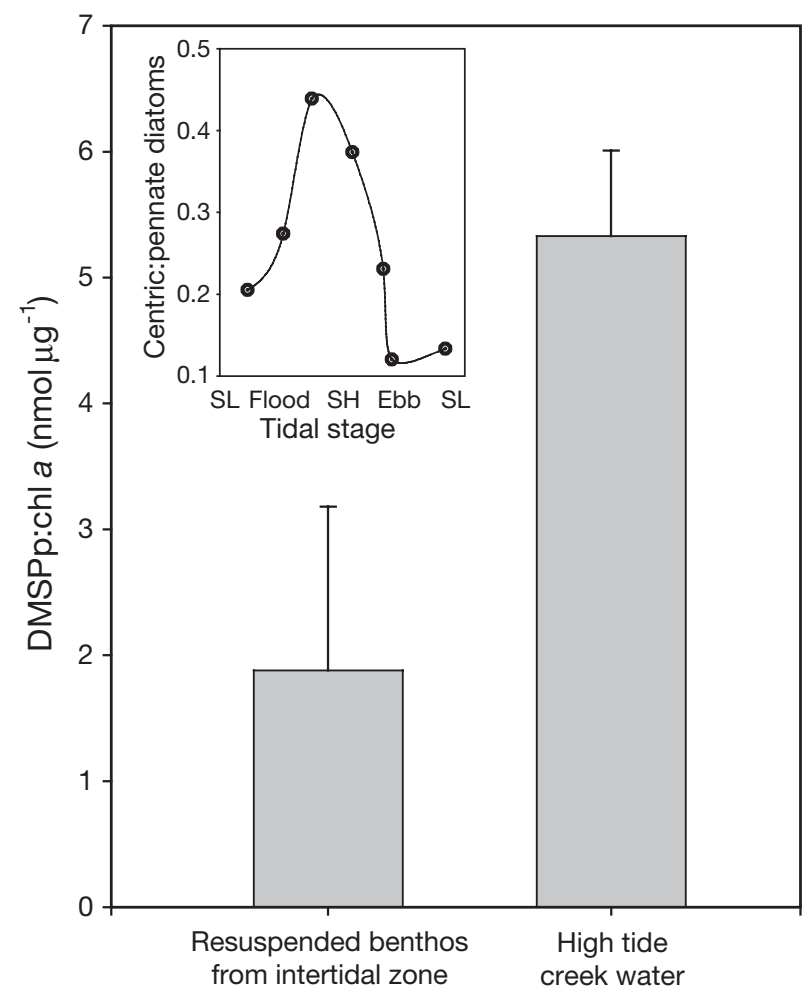

Fig 9. Comparison of DMSPp:chl a ratio of tidal creek (Clambank) water $(\mathrm{n}=3)$ with resuspended sediment from an adjacent intertidal salt marsh zone $(n=4)$. Sediment (along with benthic organisms) from the intertidal zone was suspended in the water column by gentle agitation before sampling. All samples were taken at slack high tide (SH). Inset: ratio of centric to pennate diatom cell densities in tidal-creek waters at different stages of tidal cycle. SL: slack low tide. See 'Materials and methods' for details 


\section{DMSPp:chl $a$ in intertidal benthic samples}

The contribution of benthic flora likely to be resuspended by the rapidly ebbing water currents in the shallow waters that drain into Clambank Creek at low tide was also examined. The DMSPp:chl a ratio in this water with resuspended sediment from the intertidal zone composed of areas of open mud flats and Spartina alterniflora-dominated vegetation was significantly lower than that from undisturbed creek water at high tide (Fig. 9). Since chl a was almost the same for both, the low DMSP content in the suspended benthic flora (mostly pennate diatoms) appears to account for this reduced ratio in the tidal creek during low tide, but it is not known how assemblages would react to these factors in situ.

\section{DISCUSSION}

The objective of this study was to examine the dynamics of particulate DMSP in estuarine tidal creeks as it related to phytoplankton community composition. Although phytoplankton are known to be the major source of DMSPp in the marine environment (Kiene et al. 1996), only a weak correlation between chl $a$ and DMSPp was found in the salt marsh tidal creeks studied here. Similar weak correlations have been reported from large geographical areas of the world's oceans (Kettle et al. 1999), coastal waters (Turner et al. 1988) and the North Atlantic (Dacey et al. 1998). This was generally attributed to variations in the taxonomic make-up of the DMSP-producing phytoplankton assemblages (Dacey et al. 1998). Phytoplankton groups shown to produce significant amounts of DMSP include pyrmnesiophytes, chrysophytes and dinoflagellates, while culture studies have reported that diatoms, chlorophytes and cyanobacteria produce very little (Keller et al. 1989a, DiTullio et al. 2000). It should be noted however that the physiological state, as influenced by such factors as light intensity and salinity, greatly affects the amount of DMSP produced (Dickson \& Kirst 1986, Van Bergeijk et al. 2002). In oceanic waters where the phytoplankton assemblage was dominated by 1 or 2 known DMSP-producing species, their correlation with DMS emission was relatively high (Barnard et al. 1984, Gibson et al. 1990, Belviso et al. 1993, Malin et al. 1993, Matrai \& Keller 1993, Cantin et al. 1996, Scarratt et al. 2002). In areas where DMS and DMSPp could not be attributed to a dominant DMSPproducing species, correlations with biomass were relatively low. In these situations, attempts were made (with limited success) to relate specific photopigments to a particular DMSP-producing phytoplankton class or species (Belviso et al. 1993, 2001, Dacey et al. 1998).
Dacey et al. (1998), for example, found poor correlations of DMS and DMSP with both chl $a$ and the photopigments of known DMSP-rich taxa of the Sargasso Sea, leading to their suggestion that taxa of unknown pigment composition accounted for DMSP in those waters.

In our study, changes in the DMSP:chl a ratio in a North Inlet tidal creek were correlated with changes in phytoplankton community structure based on pigments (Table 1). A high positive correlation coefficient (r) was found in tidal stage variations between this ratio and pigment-based biomass of Haptophyceae B, Dinophyceae B, Cryptophyceae and Cyanophyceae. The Haptophyceae B can be a difficult group to verify microscopically because their cells are relatively small $(<10 \mu \mathrm{m})$ and some species are not amenable to Lugol preservation. Pigment-based identification is therefore advantageous with this group, particularly because they have the distinction of containing both $19^{\prime}$ but and 19 'hex. Both haptophytes and dinoflagellates generally have high capabilities for producing DMSP (Keller et al. 1989a,b, Scarratt et al. 2002). In our microscopic observations, Chrysochromulina spp. (Haptophyceae) were relatively more abundant from $2 \mathrm{~h}$ before slack high tide to $2 \mathrm{~h}$ after slack high than in the other tidal periods (data not shown). In fact, these taxa were not detected at slack low tide. Chrysochromulina spp. are known more from marine (Jeffrey et al. 1997) than from estuarine environments, consistent with our assumption that this group was advected with flood tidal flow. Dinophyceae B includes peridinin-containing dinoflagellates such as Amphidinium and Prorocentrum, genera that are known for high DMSP production (Keller et al. 1989a,b). Although Prorocentrum spp. showed no clear trend with tidal stage during this experiment, Amphidinium spp. were detected only at slack high tide (peak of $21 \mathrm{cells} \mathrm{ml}^{-1}$ ) and $2 \mathrm{~h}$ after high tide $\left(2\right.$ cells ml$\left.^{-1}\right)$.

The positive relationship of Cyanophyceae with DMSP:chl $a$ is puzzling because cyanobacteria (including Synechococcus spp., the most abundant cyanobacterial taxon in North Inlet tidal creeks [Lewitus et al. 1998]) are reported to have a low or no capacity for DMSP production (Keller et al. 1989a, Van Bergeijk $\&$ Stal 1996). Since these reports were from culturebased experiments, they might not represent DMSP levels in cyanobacteria in their natural physiological state. Another explanation for their apparent correlation with DMSPp levels is the possibility that the CHEMTAX-derived cyanobacterial group was misrepresented because zeaxanthin is the only signature pigment used to identify this group, and it is also common to other phytoplankton groups. However, inconsistent with this explanation, other zeaxanthin-containing groups (e.g. chlorophytes, prasinophytes) are also reported to have low DMSP-producing capabilities 
(Keller et al. 1989a), and biomass of at least 1 of these taxa (prasinophytes as represented by Prasino-A or Prasino-B) was found to vary negatively with DMSP:chl a. Finally, it is possible that cyanobacteria correlation with DMSPp:chl $a$ is due to simple covariance with species of high-DMSP producers. Cyanobacterial isolates from microbial mats have been reported to contribute only small amounts of DMSP to sediments in intertidal zones (Visscher \& Van Gemerden 1991, Jonkers et al. 1998). However, these intertidal zones are known to contain relatively higher amounts of DMSP (Kiene 1988, Visscher et al. 1994, Van Bergeijk \& Stal 1996, Van Bergeijk et al. 2002), some of which is thought to be from diatoms and cyanobacteria (Jonkers et al. 1998).

Diatoms were very abundant throughout the tidal cycle, and although they also produce relatively low DMSP levels on a per cell basis, their dominant contribution to tidal-creek phytoplankton biomass in North Inlet during the fall (present Fig. 7 and Lewitus et al. 1998) suggests a potentially high contribution to total particulate DMSP at all tidal stages. Our observations (Fig. 9, inset) show that the ratio of centric to pennate diatoms in the tidal-creek waters followed a pattern similar to that of the DMSPp:chl a ratio during the tidal cycle, both of which peaked at high tide. This suggests that more centric diatoms are advected from the coastal waters into the tidal-creek waters during the flood tide, increasing this ratio. At low tides, these centric diatoms are transported back to the coastal waters and the pennate diatoms are resuspended in the tidal-creek water column, thereby decreasing the centric:pennate ratio. Since most benthic diatoms are pennate species (Sullivan 1975,1977, 1978), it is possible that centric diatoms being advected from the coastal waters contribute more to the DMSP:chl a ratio relative to the pennates resuspended from the intertidal zone. This would help explain the moderate positive correlation of diatoms to the DMSP:chl a ratio during the tidal cycle.

Alternatively, the moderate positive correlation between diatoms and the DMSPp:chl a ratio could be due in part to Kryptoperidinium spp. and Scrippsiella spp. (Dinophyceae A), which are grouped with diatoms because of similar pigment composition since the chloroplasts of these dinoflagellates are thought to be derived from endosymbiotic ancestral diatoms (Chesnick et al. 1997, Kempton et al. 2002). Furthermore, dinoflagellete species were observed microscopically throughout the tidal cycle (data not shown). Finally, the correlation of diatoms with DMSP:chl $a$ in the tidal cycle could be a combination of both phenomenon.

Apart from the change in phytoplankton assemblage during the tidal cycle as seen in these experiments, it is also possible that the changes observed in the DMSP and chl a values were due to physiological factors like light intensity, salinity or nutrient levels, or a combination of these factors. chl a levels are known to change severalfold in turbid waters such as tidal creeks, and similar results are reported here (Fig. 3). Since chl a was used here as a biomass indicator, such a phenomenon could render our DMSPp:chl a ratios meaningless. However, the observed increases in the phytoplankton DMSPp pool occurred at the same time as chl a was increasing, meaning that either DMSP pools per cell were increasing dramatically or an assemblage of DMSP-rich cells was entering with the high tide. Furthermore, the DMSPp:chl a ratio also increased at high tide and decreased at low tide regardless of time of day (see Fig. 5), which seems to preclude light as a factor in this phenomenon.

Salinity, which also affects DMSP levels in phytoplankton both in situ and in culture (Vairavamurthy et al. 1985, Iverson et al. 1989), only changed marginally during these tidal cycles, from 34 at low tide to ca. 36 psu at high tide. Although these salinity changes are small, they are known to affect DMSP levels in phytoplankton (Iverson et al. 1989, Kulkarni unpubl. data). It is not clear at this time if these changes in DMSPp levels were due to changes in intracellular pool size, or to changes in the phytoplankton assemblages which were shown in this study to be pronounced (Fig. 8). The possibility exists that both increased salinity and a change in phytoplankton composition account for the increase in DMSPp during high tides.

Recently, the role of DMSP has been shown to be important as a countermeasure against nutrient stress in phytoplankton (Harada et al. 2004, Keller et al. 2004, Riseman \& DiTullio 2004). While one study showed that the DMSPp:chl a ratio in seawater samples decreased in response to added nutrients (Harada et al. 2004), another showed variable responses to the addition of different nitrogen sources from various depths incubated aboard ship (Keller et al. 2004). Neither Harada et al. (2004) nor Keller et al. (2004) were sure if the resulting change in DMSPp levels was a result of a physiological change in the existing population or was due to preferential growth of species low in DMSP. While we do not have measurements of nutrients for the tidal cycles reported here, $\mathrm{NH}_{4}{ }^{+}$and $\mathrm{PO}_{4}{ }^{3-}$ have been reported to be higher at low tide and lower at high tide in Clambank creek (Morris 2000, Belle W. Baruch Institute for Marine Biology and Coastal Research 2000). Recall that, in our experiments, the DMSPp:chl a ratio was lowest at low tide, which is in general agreement with Harada et al.'s (2004) findings that this ratio decreased with added nutrients $\left(\mathrm{NH}_{4}{ }^{+}\right.$and $\left.\mathrm{PO}_{4}{ }^{3-}\right)$. Again it remains unclear whether these decreases in DMSPp:chl a ratio at low tide were due to nutrient input or to a change in phytoplankton assemblage that occurred with the changing tidal stage. Fe addition can also reduce nutritional stress on 
phytoplankton populations, as evidenced by a decrease in DMSPp:chl a ratio measured during shipboard incubation and in situ studies (Sunda et al. 2002, Riseman \& DiTullio 2004). Riseman \& DiTullio (2004) concluded that this result was probably due to a change from a phytoplankton assemblage dominated by cryptophytes and haptophytes to one dominated by diatoms.

In summary, our results suggest that tidal variability of chl a-normalized DMSPp seems to be best explained by changes in phytoplankton species composition that occur during a tidal cycle, although changes in cellular physiological properties cannot be ruled out as an additional or alternative explanation. We suggest that advection of DMSP-rich, coastal, ocean phytoplankton (haptophytes, dinoflagellates) into tidal creeks elevates the DMSP:chl a ratio during flood tide, and advection of low DMSP-containing phytoplankton from the estuarine intertidal habitat (prasinophytes, chlorophytes, 19'but-containing chrysophytes and diatoms; Baillie \& Welsh 1980, Shaffer \& Sullivan 1988) no doubt leads to reduced ratios during ebb tide (Fig. 9). Further research is needed to assess the DMSP production capabilities within the Bacillariophyceae (i.e. between benthic and planktonic taxa, or between coastal marine and estuarine species).

Acknowledgements. We acknowledge the Belle W. Baruch Institute of Marine Biology and Coastal Research for access to research sites, laboratory facilities, maps and images. The initial phase of the research was supported by the South Carolina Sea Grant Consortium. We also acknowledge support from NOAA grants NA90AA-D-SG672 and NA06OA0675, and EPA grant R826944-01-0. Contribution 1403 of the USC Belle W. Baruch Institute.

\section{LITERATURE CITED}

Ackman RG, Tocher CS, McLachlan J (1966) Occurrence of dimethyl-B-propiothetin in marine phytoplankton. J Fish Res Board Can 23:357-364

Andreae MO, Barnard WR (1984) The marine chemistry of dimethylsulfide. Mar Chem 14:267-279

Arar EJ, Collins GN (1997) In vitro determination of chlorophyll $a$ in marine and freshwater algae by fluorescence. Methods for the determination of chemical substances in marine and estuarine environmental samples. Method 445.0 (revision 1.2) EPA/600/R-92/121, US Environmental Protection Agency, Washington, DC

Baillie PW, Welsh BL (1980) The effect of tidal resuspension on the distribution of intertidal epipelic algae in an estuary. Estuar Coast Mar Sci 10:165-180

Barnard WR, Andreae MO, Iverson RL (1984) Dimethylsulfide and Phaeocystis pouchetii in the southeastern Bering Sea. Cont Shelf Res 3:103-113

Belle W Baruch Institute for Marine Biology and Coastal Research (2000) Baruch Institute's long-term estuarine monitoring database for the North Inlet Estuary, South Carolina: 1981-2000. Baruch Marine Field Laboratory, University of South Carolina, Georgetown, SC
Belviso S, Buat-Ménard P, Putaud JP, Nguyen BC, Claustre H, Neveux J (1993) Size distribution of dimethylsulfoniopropionate (DMSP) in areas of the tropical northern Atlantic Ocean and the Mediterranean Sea. Mar Chem 44:55-71

Belviso S, Claustre H, Marty JC (2001) Evaluation of the utility of chemotaxonomic pigments as a surrogate for particulate DMSP. Limnol Oceanogr 46:989-995

Cantin G, Levasseur M, Gosselin M, Michaud S (1996) Role of zooplankton in the mesoscale distribution of surface dimethylsulfide concentrations in the Gulf of St. Lawrence, Canada. Mar Ecol Prog Ser 141:103-117

Chesnick JM, Kooistra WHCF, Wellbrock U, Medlin LK (1997) Ribosomal RNA analysis indicates a benthic pennate diatom ancestry for the endosymbionts of the dinoflagellates Peridinium foliaceum and Peridinium balticum (Pyrrhophyta). J Eukaryot Microbiol 44:314-320

Dacey JWH, Howse FA, Michaels AF, Wakekham SG (1998) Temporal variability of dimethylsulfide and dimethylsulfoniopropionate in the Sargasso Sea. Deep-Sea Res I 45: 2085-2104

DeLaune RD, Devai I, Lindau CW (2002) Flux of reduced sulfur gases along a salinity gradient in Louisiana coastal marshes. Estuar Coast Shelf Sci 54:1003-1011

de Souza MP, Yoch DC (1995) Purification and characterization of dimethylsulfoniopropionate lyase from an Alacaligenes-like dimethylsulfide-producing marine isolate. Appl Environ Microbiol 61:21-26

Dickson DMJ, Kirst GO (1986) The role of dimethylsulfoniopropionate, glycine betaine and homarine in the osmoacclimation of Platymonas subcordiformis. Planta 167:536-543

Dickson DMJ, Wyn Jones RG, Davenport J (1980) Steady state osmotic adaptation in Ulva lactuca. Planta 150: 158-165

DiTullio GR, Grebmeier JM, Arrigo KR, Lizotte MP and 5 others (2000) Rapid and early transport of Phaeocystis antarctica blooms in the Ross sea, Antarctica. Nature 404:595-598

Gibson JAE, Garrick RC, Burton HR, McTaggart AR (1990) Dimethylsulfide and the alga Phaeocystis pouchetii in Antarctic waters. Mar Biol 104:339-346

Harada H, Rouse MA, Sunda W, Kiene RP (2004) Latitudinal and vertical distributions of particle-associated dimethylsulfoniopropionate (DMSP) lyase activity in the western North Atlantic Ocean. Can J Fish Aquat Sci 61:700-711

Higgins HW, Mackey DJ (2000) Algal class abundances, estimated from chlorophyll and carotenoid pigments, in the western Equatorial Pacific under El Niño and non-El Niño conditions. Deep-Sea Res I 47:1461-1483

Iverson RL, Nearhoff FL, Andreae MO (1989) Production of dimethylsulfonium propionate and dimethylsulfide by phytoplankton in estuarine and coastal waters. Limnol Oceanogr 34:53-67

Jeffrey SW, Mantoura RFC, Wright SW (eds) (1997) Phytoplankton pigments in oceanography: guidelines to modern methods. In: SCOR/UNESCO monographs on oceanographic methodology 10. UNESCO, Paris, p 661

Jonkers HM, Koopmans GF, Van Gemerden H (1998) Dynamics of dimethyl sulfide in a marine microbial mat. Microb Ecol 36:93-100

Keller MD, Bellows WK, Guillard RRL (1989a) Dimethylsulfide production in marine phytoplankton. In: Saltzmann ES, Cooper M (eds) Biogenic sulfur in the environment. American Chemical Society Symposium Series. American Chemical Society, Washington, p 167-182

Keller MD, Bellows WK, Guillard RRL (1989b) Dimethylsulfide production in marine phytoplankton: an additional impact of unusual blooms. In: Cosper EM, Bricejl VM, 
Carpenter EJ (eds) Novel phytoplankton blooms. Causes and impacts of recurrent brown tides and other unusual blooms. Springer-Verlag, Berlin, p 101-115

Keller MD, Matrai PA, Kiene RP, Bellows WK (2004) Responses of coastal phytoplankton populations to nitrogen additions: dynamics of cell-associated dimethylsulfoniopropionate (DMSP), glycine betaine (GBT), and homarine. Can J Fish Aquat Sci 61:685-699

Kempton JW, Wolny J, Tengs T, Rizzo P and 6 others (2002) Kryptoperidinium foliaceum blooms in South Carolina: a multi-analytical approach to identification. Harmful Algae $1: 383-392$

Kettle AJ, Andreae MO, Amouroux D, Andreae TW and 28 others (1999) A global database of sea surface dimethylsulfide (DMS) measurements and a procedure to predict sea surface DMS as a function of latitude, longitude, and month. Global Biogeochem Cycles 13:399-444

Kiene RP (1988) Dimethyl sulfide metabolism in salt marsh sediments. FEMS Microbiol Ecol 53:71-78

Kiene RP, Visscher PT, Keller MD, Kirst GO (eds) (1996) Biological and environmental chemistry of DMSP and related sulfonium compounds. Plenum Press, New York

Kjerfve B (1986) Circulation and salt flux in a well mixed estuary. In: Van de Kreeke J (ed) Physics of shallow estuaries and bays. Springer-Verlag, New York, p 22-29

Leck C, Larsson U, Bagander LE, Johansson S, Hajdu S (1990) Dimethylsulfide in the Baltic Sea: annual variability in relation to biological activity. J Geophys Res 95:3353-3363

Lewitus AJ, Koepfler ET, Morris JT (1998) Seasonal variation in the regulation of phytoplankton by nitrogen and grazing in a salt marsh estuary. Limnol Oceanogr 43:636-646

Lewitus AJ, Hayes KC, Willis BM, Burkholder JM and 5 others (2002) Low abundance of the dinoflagellates, Pfiesteria piscicida, P. shumwayae, and Cryptoperidiniopsis spp. in South Carolina tidal creeks and open estuaries. Estuaries 25:586-597

Lewitus AJ, White DL, Tymowski RG, Geesey ME, Hymel SN, Noble PA (2005) Adapting the CHEMTAX method for assessing phytoplankton taxonomic composition in southeastern US estuaries. Estuaries 28:158-170

Mackey MD, Mackey DJ, Higgins HW, Wright SW (1996) CHEMTAX - a program for estimating class abundances from chemical markers: application to HPLC measurements of phytoplankton. Mar Ecol Prog Ser 144:265-283

Malin G, Turner S, Less P, Hooligan P, Harbor D (1993) Dimethylsulfide and dimethylsulfoniopropionate in the Northeast Atlantic during the summer coccolithophore bloom. Deep-Sea Res I 40:1487-1508

Matrai PA, Keller MD (1993) Dimethylsulfide in a large-scale coccolithophore bloom in the Gulf of Maine. Cont Shelf Res 13:831-843

Morris JT (2000) Effects of sea level anomalies on estuarine processes. In: Hobbie J (ed) Estuarine science: a synthetic approach to research and practice. Island Press, Washington, DC, p 107-127

Riseman SF, DiTullio GR (2004) Particulate dimethylsulfoniopropionate and the dimethylsulfoxide in relation to iron availability and algal community structure in the Peru upwelling system. Can J Fish Aquat Sci 61:721-735

Roman MR, Tenore KR (1978) Tidal resuspension in Buzzards Bay, Massechusetts. Estuar Coast Mar Sci 6:37-46

SAS Institute (1999) SAS user's guide: statistics. Version 8e. SAS Institute, Cary, NC

Scarratt MG, Levasseur M, Michaud S, Cantin G, Gosselin M, de Mora SJ (2002) Influence of phytoplankton taxonomic profile on the distribution of dimethylsulfide and dimethyl- sulfoniopropionate in the northwest Atlantic. Mar Ecol Prog Ser 244:49-61

Shaffer GP, Sullivan MJ (1988) Water column productivity attributable to displaced benthic diatoms in well-mixed shallow estuaries. J Phycol 24:132-140

Simó R (2001) Production of atmospheric sulfur by oceanic plankton: biogeochemical, ecological and evolutionary links. Trends Ecol Evol 16:287-294

Steudler PA, Peterson BJ (1984) Contribution of gaseous sulphur from salt marshes to the global sulphur cycle. Nature 311:455-457

Sullivan MJ (1975) Diatom communities from Delaware salt marsh. J Phycol 11:384-390

Sullivan MJ (1977) Edaphic diatom communities associated with Spartina alterniflora and $S$. patens in New Jersey. Hydrobiologia 53:81-86

Sullivan MJ (1978) Diatom community structure: taxonomic and statistical analyses of a Mississippi salt marsh. J Phycol 12:205-210

Sunda W, Kleber DJ, Kiene RP, Huntsman S (2002) An antioxidant function for DMSP in marine algae. Nature 418: $317-320$

Turner SM, Malin G, Liss PS, Harbour DS, Holligan PM (1988) The seasonal variation of dimethylsulfide and dimethylsulfoniopropionate concentrations in nearshore waters. Limnol Oceanogr 33:364-375

Utermöhl H (1958) Zur Vervollkommnung der quantitativen Methodik. Mitt Int Ver Theor Anngew Limnol 9:1-38

Vairavamurthy A, Andreae MO, Iverson RL (1985) Biosynthesis of dimethylsulfide and dimethylpropiothetin by Hymenomonas carterae in relation to sulfur source and salinity variations. Limnol Oceanogr 30:59-70

Van Bergeijk SA, Stal LJ (1996) The role of phototrophic microorganisms in production and conversion of dimethylsulfoniopropionate and dimethylsufide in microbial mats. In: Kiene RP, Visscher PT, Keller MD, Kirst GO (eds) Biological and environmental chemistry of DMSP and related sulfonium compounds. Plenum Press, New York, p 369-379

Van Bergeijk SA, Schönefeldt K, Stal LJ, Huisman J (2002) Production and consumption of dimethylsulfide (DMS) and dimethylsulfoniopropionate (DMSP) in a diatomdominated intertidal sediment. Mar Ecol Prog Ser 231: $37-46$

Van Heukelem L, Tomas CS (2001) Computer-assisted highperformance liquid chromatography method development with applications to the isolation and analysis of phytoplankton pigments. J Chromatogr A 910:31-49

Van Heukelem L, Lewitus AJ, Kana TM (1992) Highperformance liquid chromatography of phytoplankton pigments using a polymeric reversed-phase C18 column. J Phycol 28:867-872

Van Heukelem L, Lewitus AJ, Craft NE (1994) Improved separations of phytoplankton pigments using temperaturecontrolled high performance liquid chromatography. Mar Ecol Prog Ser 114:303-313

Visscher PT, Van Gemerden H (1991) Production and consumption of dimethylsulfoniopropionate in marine microbial mats. Appl Environ Microbiol 57:3237-3242

Visscher PT, Kiene RP, Taylor BF (1994) Demethylation and cleavage of dimethylsulfoniopropionate in marine intertidal sediments. FEMS Microbiol Ecol 14:179-190

Wright SW, Van den Enden RL (2000) Phytoplankton community structure and stocks in the East Antarctic marginal ice zone (BROKE survey, January-March 1996) determined by CHEMTAX analysis of HPLC pigment signatures. Deep-Sea Res II 47:2363-2400 
Wright SW, Thomas DP, Marchant HJ, Higgins HW, Mackey MD, Mackey DJ (1996) Analysis of phytoplankton of the Australian sector of the Southern Ocean: comparisons of microscopy and size frequency data with interpretations of pigment HPLC data using the 'CHEMTAX' matrix factorization program. Mar Ecol Prog Ser 144:285-298

Yoch DC (2002) Dimethylsulfoniopropionate: its sources, role

Editorial responsibility: Kenneth Heck (Contributing Editor), Dauphin Island, Alabama, USA in the marine food web, and biological degradation to dimethylsulfide. Appl Environ Microbiol 68:5804-5815

Zubkov MV, Fuchs BM, Archer SD, Kiene RP, Amann R, Burkill PH (2001) Linking the composition of bacterioplankton to rapid turnover of dissolved dimethylsulfoniopropionate in an algal bloom in the North Sea. Environ Microbiol 3:304-311

Submitted: January 9, 2004; Accepted: November 9, 2004 Proofs received from author(s): March 9, 2005 